\title{
Chemical Profiling and Wetting Behaviors of Endemic Salvia absconditiflora Greuter \& Burdet (Lamiaceae) Collected from Gypsum Areas
}

\author{
Aysenur Kayabas ${ }^{1}$ (D), Ertan Yildirim² \\ 'Çankırı Karatekin University, Faculty of Science, Department of Biology, Çankırı, Turkey \\ 2Gazi University, Faculty of Science, Department of Chemistry, Ankara, Turkey
}

ORCID IDs of the authors: A.K. 0000-0003-3555-4399; E.Y. 0000-0002-4083-3408

Please cite this article as: Kayabas A, Yildirim E. Chemical Profiling and Wetting Behaviors of Endemic Salvia absconditiflora Greuter \& Burdet (Lamiaceae) Collected from Gypsum Areas. Eur J Biol 2022; 81(1): 1-10. DOI: 10.26650/EurJBiol.2021.1011530

\begin{abstract}
Objective: Salvia absconditiflora Greuter \& Burdet is an endemic plant and survives in nature by adapting to extreme conditions. The aims of this study are to characterize and compare the diversity in the spectral-chemical structure of S. absconditiflora's plant parts using the FTIR spectroscopy technique, to determine the wettability of the adaxial and abaxial epidermal surfaces of $S$. abscontidiflora leaves and to interpret whether there is a difference between the contact angle (CA) measurements at the points determined in the surface area of the leaves from the part close to the petiole to the leaf tip.
\end{abstract}

Materials and Methods: The ATR-FTIR spectra for the chemical content of S. absconditiflora were obtained from six different plant parts and information about their chemical compositions was obtained. CA measurements were carried out for the natural events of the leaf area, especially for the water holding capacity or hydrophilic-hydrophobic characteristics.

Results: The biochemical fingerprint of S. absconditiflora was determined by the analysis of chemical groups in vegetative and generative plant parts using ATR-FTIR spectroscopy. The CAs showed that the leaf had a hydrophobic character. In addition, leaf hysteresis was determined for each plant part, and it was understood that the lotus effect also appeared in $S$. absconditiflora.

Conclusion: Detailed biochemical profiling, wettability, and hysteresis reports of S. absconditiflora were created for the first time. With this study, important clues about the adaptation of plants to harsh conditions were obtained.

Keywords: ATR-FTIR spectroscopy, contact angle, gypsum, hysteresis, Salvia leaf

\section{INTRODUCTION}

Lamiaceae is a family rich in wild aromatic plant species and antioxidant compounds beneficial to humans (1). The Lamiaceae family is divided into seven subfamilies: Ajugoideae, Lamioideae, Nepetoideae, Scutellarioideae, Viticoideae, Symphorematoideae and Prostantheroideae, the first five of which are grown in Turkey (1). Salvia $\mathrm{L}$. is one of the largest belonging to the Lamiaceae (2) and is known as 'adaçayı (sage)' in Turkey (3). It is known that Salvia taxa, which have antibacterial, carminative, stimulant, diuretic, and spasmolytic properties, have been used for treatment since the earliest times (4-6). Salvia, the diversity of which varies according to leaf shapes, calyx structure, length, and color of petals, has 100 species and 107 taxa in the flora of Turkey (7-10), and Turkey is very important in terms of its import and use (11). Salvia absconditiflora Greuter \& Burdet (Synonym: S. cryptantha Montbret \& Aucher ex Bentham) is a perennial and endemic plant. The life form is the whole adaptation of the plant to the climate, and it is assumed in the literature that it develops in response to 
environmental conditions (12). The life form of S. absconditiflora, which generally spreads on rocky limestone slopes, dry steppes, fallow fields, and roadsides, is hemicryptophyte (13) and its flowering time is from May to August.

Gypsum habitats with rare, threatened, and endemic plants are one of the most illustrative examples of natural stressful environments (14). Depending on the substrate factor, gypsum plants are faced with both the physical and chemical stress of the soil and arid climatic conditions. For plants growing in gypsum soils containing $\mathrm{CaSO}_{4} \cdot 2 \mathrm{H}_{2} \mathrm{O}$, soil salinity is also a consideration (14). When plants are exposed to salinity, certain biochemical changes occur in plant tissues which maintain an osmotic balance between soil and these tissues. These changes cause the accumulation or loss of biochemicals such as carbohydrates, amines, and lipids (15). Plants develop morphological, physiological, ecophysiological, and biochemical adaptations to tolerate substrate factors such as soil salinity. Examining the properties of leaves under salt stress is an important way to study abiotic stress situations (16).

The use of infrared (IR) spectroscopy in biological samples dates to the 1950s (17). After the development of IR spectroscopy, Fourier transform infrared (FTIR) spectroscopy became a valuable instrument for distinguishing and identifying different samples (18). Attenuated total reflection-Fourier transform infrared (ATR-FTIR) spectroscopy is also a tool with many advantages due to features such as being able to perform the analysis in a short time without the need for sample dilution and more frequent reproducibility (19). Furthermore, in ATR-FTIR spectroscopy, ATR measurement is independent of sample thickness and can be measured even when the biological sample is small (20).

The fact that FTIR spectroscopy allows the investigation of biological samples as well as gases, liquids, and solids, has made it powerful (18). FTIR provides effective data on the molecular structure and chemical composition of biological samples. These fingerprints even make it possible to trace changes in the molecular composition of human cancer diseases today (21).

In addition to its use in human health, FTIR is also used to monitor plant physiological processes such as environmental stress, leaf senescence, and aging (22). Wahab et al. reported that FTIR helped identify the use of Cactus leaves fibers in wastewater treatment for ammonium removal as a recycling strategy (23). Palacio et al. investigated the ability of gypsum plants to distinguish groups by comparing the main chemical groups in the leaves of plant groups specialized for gypsum habitats with the help of FTIR spectroscopy (24). Woutersen et al. interpreted the evolutionary history of Nitraria by determining the chemical composition of pollen walls with FTIR spectroscopy (25). To understand the osmotic balance between the roots, which are the most important organs in the connection of plants with the soil, and the soil solution, biochemicals are determined with expensive equipment such as HPLC and GS-MS (26), together with xylem sap analysis (27). However, the use of FTIR spectroscopy in stress studies is recommended more due to its advantages such as time efficiency and cheapness (15).
Wetting, which occurs because of the interaction of water with a surface, has a critical importance in plants. The water contact angle (CA) with the surface is the angle at which water, air, and solid meet, and it is also a measure that represents the probability of the surface being wetted by water (28). Leaf wetting is effective in reducing water loss from intense transpiration, thus limiting water depression by keeping the relations between the plant and water in balance (29-30). The plant surfaces exhibit hydrophobic or hydrophilic properties depending on their affinity for wetness (31). As the surface hydrophobicity increases, the contact angle hysteresis (CAH) decreases in parallel with the increase in water contact angles (CAs) (32). Super hydrophobicity is very important in wetting studies, where both the water contact angle is greater than $150^{\circ}$ and the hysteresis is less than $10^{\circ}$. Super hydrophobicity is often associated with very low adhesive surfaces. The best example of a low stickiness surface and super hydrophobicity is the lotus effect, which comes from the waterproofing of the lotus leaf. The lotus effect was first described by Neinhuis and Barthlott (33), and it was reported that the water-repellent effect of the lotus leaf resulted from its complex morphology. Studies on hydrophobic natural surfaces were generally inspired by the lotus leaf (34) and Salvia was interpreted for the first time.

In this study, endemic S. absconditiflora Greuter \& Burdet growing in gypsum habitats was examined. To the best of our knowledge, there are no literature reports regarding the FTIR spectroscopy analysis and CA measurements of S. absconditiflora. Two main objectives of this study were: (i) to characterize and compare the diversity in the spectral-chemical structure of vegetative and generative organs of $S$. absconditiflora using the FTIR spectroscopy technique; and (ii) to determine the wettability of the adaxial and abaxial epidermal surfaces of S. abscontidiflora leaves and to interpret whether there is a difference between the CAs at the points determined in the surface area of the leaves.

\section{MATERIALS AND METHODS}

\section{Species Selection and Study Area}

The endemic Salvia absconditiflora samples were collected from around the Aşağıpelitözü village (950-1000 m a.s.l., 40²9' $\mathrm{N}, 33^{\circ} 41^{\prime} \mathrm{E}$ ) in the Çankırı province in the northern part of Central Anatolia from May to June 2021 (Figure 1). In this study, S. absconditiflora was taken from gypsum areas (Figure 1d). After it was brought to the laboratory, it was freed from residues. Damaged plant parts were not included in the analysis. The plant was identified taxonomically according to Davis et al. (35). The plant material identification was determined by the author (A. Kayabaş). After plant identification, the vegetative and generative parts were dried in a shady and ventilated room. The plant samples were stored in Çankırı Karatekin University as part of a personal collection. When evaluated climatically, the climate in Çankırı, which is approximately $250 \mathrm{~km}$ away from the sea, is continental and a semi-arid climate prevails (36). When examined geologically, gypsum formations are common in the Çankırı province and its surroundings (36). 

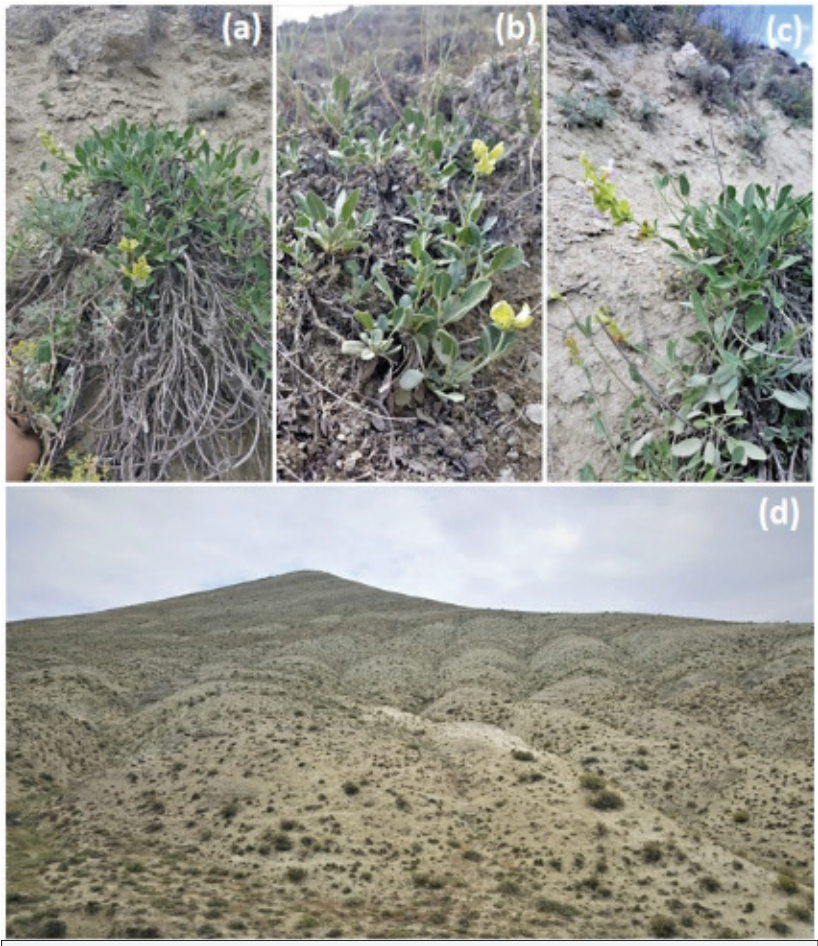

Figure 1. Salvia absconditiflora Greuter \& Burdet (Photos by A. Kayabaş) a. Plant habit, b. Early-stage of plant, c. Late-stage of plant d. Gypsum habitat in which the species grows.

\section{ATR-FTIR Spectroscopic Analysis}

The infrared spectra of the dried root, stem, leaf, petiole, and flower were obtained using ATR-FTIR spectroscopy, model Thermo Nicolet 6700, supplied by OMNIC software and recorded at room temperature in the wavenumber range from 400 to $4000 \mathrm{~cm}^{-1}$ at a resolution of $4 \mathrm{~cm}^{-1}$, accumulating 32 scans per spectrum.

\section{Leaf CAs Measurement}

The CA measurements of the S. absconditiflora leaves were carried out at room temperature using a Krüss DSA 100 goniometer. A drop of deionized water $(4 \mu \mathrm{L}, 18 \mathrm{M} \Omega \mathrm{cm}$ resistivity) was used as the wetting liquid. Three contact angle values were obtained from three different parts between the petiole and the leaf tip and then averaged. The leaf veins were avoided in the measurements.

\section{RESULTS}

ATR-FTIR spectroscopy gave detailed results for the analysis of organic matter chemical groups in the vegetative and generative plant parts of $S$. absconditiflora. The results contributed to the determination of the biochemical fingerprint of $S$. absconditiflora. Starting from the root of S. absconditiflora, the ATR-FTIR spectra of each plant part were taken. The ATR-FTIR spectra of the root, stem, petiole, leaf, sepal, and petal are shown in Figure 2. Although there were partial shifts in the band regions seen in the ATR-FTIR spectra, it was determined that there was not much change. It was found that the chemical groups of the ATR-FTIR spectra for each segment were similar and the band regions were close (Table 1). It was determined that there were changes in the intensities of only some chemical groups ranging from the root to the petal.

It was determined that the $\mathrm{S}-\mathrm{O}$ bending bands in the ATR-FTIR spectrum were caused by gypsum and sulphate, and the range of these bands was between 602-595, 680-675, and 690-630 $\mathrm{cm}^{-1}$ respectively. The bands of calcium carbonate and alkane groups were found in the range of $730-710 \mathrm{~cm}^{-1}$. Calcium oxalate, lignin, and calcium carbonate sourced bands were seen in 780775 ( $\mathrm{COO}^{-}$bending), 832-825 (aromatic $\mathrm{CH}$ out of plane) and $879-872 \mathrm{~cm}^{-1}$ (C-O plane banding) bands, respectively. The band $\mathrm{C}-\mathrm{O}$ stretching, and $\mathrm{O}-\mathrm{H}$ deformation band of polysaccharides were detected at 1015-1005 $\mathrm{cm}^{-1}$. Stretching bands in silicates, phosphates and sulphates were seen significantly at 1150-950

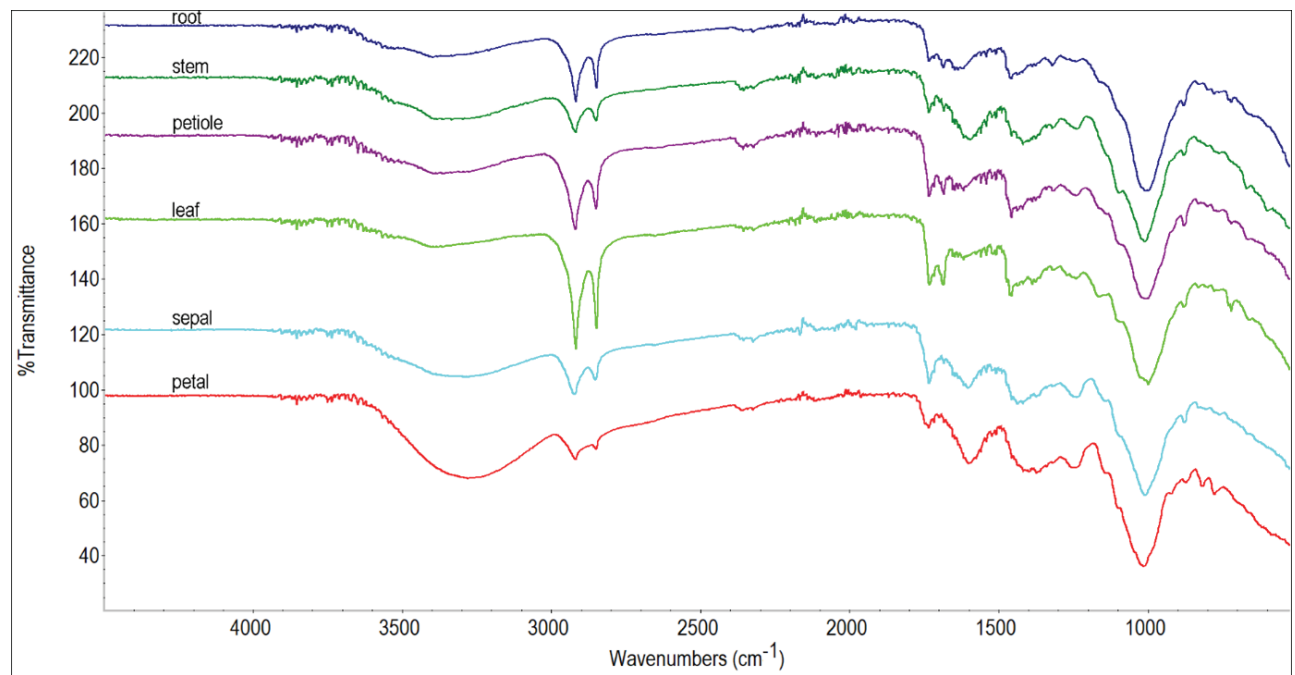

Figure 2. ATR-FTIR spectra of different parts of Salvia absconditiflora. 
Eur J Biol 2022; 81(1): 1-10

Kayabas and Yildirim. Biochemical and wettability analyses of Salvia adapted to gypsum soils

Table 1. Characteristic bands of ATR-FTIR spectra at Salvia absconditiflora.

\begin{tabular}{|c|c|c|c|c|c|c|c|}
\hline \multicolumn{6}{|c|}{ Salvia absconditiflora } & \multirow{2}{*}{ 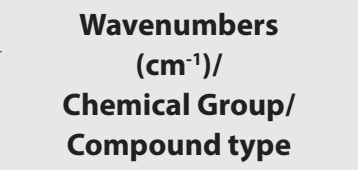 } & \multirow{2}{*}{ Ref. } \\
\hline $\operatorname{Root}\left(\mathrm{cm}^{-1}\right)$ & Stem $\left(\mathrm{cm}^{-1}\right)$ & Petiole $\left(\mathrm{cm}^{-1}\right)$ & Leaf $\left(\mathrm{cm}^{-1}\right)$ & Sepal $\left(\mathrm{cm}^{-1}\right)$ & Petal $\left(\mathrm{cm}^{-1}\right)$ & & \\
\hline$(669,600)$ & $(667,600)$ & $(667,600)$ & $(668,598)$ & $(667,597)$ & $(665,599)$ & $\begin{array}{l}669,597 \\
\text { S-O bending, } \\
\text { Gypsum }\end{array}$ & (38) \\
\hline$(680-630)$ & $x$ & $(690-650)$ & $(690-650)$ & $(680-650)$ & $(680-650)$ & $\begin{array}{l}680-610 \\
\text { S-O bending, } \\
\text { Sulphates }\end{array}$ & (37) \\
\hline (720) & $x$ & (720) & (717) & (715) & (710) & $\begin{array}{l}715 \\
\text { C-O in-plane bending, } \\
\text { Calcium carbonate }\end{array}$ & (39) \\
\hline (730) & (729) & (729) & (730) & (730) & $x$ & $\begin{array}{l}720 \\
\mathrm{CH}_{2} \text { wag, } \\
\text { Long chain (> C4) alkanes }\end{array}$ & (24) \\
\hline (775) & (779) & (775) & $(780)$ & $(780)$ & (778) & $\begin{array}{l}780 \\
\mathrm{COO}^{-} \text {bending, } \\
\text { Calcium oxalate }\end{array}$ & $(42)$ \\
\hline$(830)$ & $(832)$ & (830) & $(827)$ & $(825)$ & (820) & $\begin{array}{l}835 \\
\text { Aromatic } \mathrm{CH} \text { out of plane, } \\
\text { Lignin }\end{array}$ & $(40)$ \\
\hline (875) & (876) & $(875)$ & (879) & (879) & $(872)$ & $\begin{array}{l}874 \\
\text { C-O plane bending, } \\
\text { Calcium carbonate }\end{array}$ & (41) \\
\hline (1015) & (1010) & (1008) & $(1020)$ & (1008) & (1010) & $\begin{array}{l}1050 \\
(1030-1080) \text { Combination } \\
\text { of C-O stretching and } \\
\text { O-H deformation, } \\
\text { Polysaccharides }\end{array}$ & (43) \\
\hline$(1085-910)$ & $(1080-920)$ & $(1080-920)$ & $(1080-930)$ & $(1090-910)$ & $(1090-950)$ & $\begin{array}{l}1100-950 \\
\text { Si-O stretching, } \\
\text { Silicates }\end{array}$ & (44) \\
\hline$(1080-915)$ & $(1080-920)$ & $(1080-915)$ & $(1080-930)$ & $(1090-910)$ & $(1090-950)$ & $\begin{array}{l}\text { 1100-1000 } \\
\text { P-O stretching, } \\
\text { Phosphates }\end{array}$ & (44) \\
\hline (1135-1080) & $(1130-1080)$ & (1160-1130) & $(1180-1130)$ & $(1170-1135)$ & $(1180-1030)$ & $\begin{array}{l}1140-1080 \\
\text { S-O stretching, Sulphates }\end{array}$ & (44) \\
\hline$(1265-1220)$ & $(1280-1200)$ & $(1260-1205)$ & $(1260-1215)$ & $(1280-1200)$ & $(1280-1210)$ & $1265-1240$ & (45) \\
\hline$(1265-1220)$ & $(1280-1200)$ & (1260-1205) & $(1260-1215)$ & $(1280-1200)$ & $(1280-1210)$ & $\begin{array}{l}\text { C-O-C stretching Esters } \\
\text {............. } \\
\text { C-N stretching Amide III }\end{array}$ & (46) \\
\hline (1268) & $x$ & (1268) & (1271) & (1250) & (1260) & $\begin{array}{l}\text { 1265 } \\
\text { C-O stretching of } \\
\text { phenolic and/or aryl- } \\
\text { methyl ethers, Indicative } \\
\text { of lignin backbone }\end{array}$ & (48) \\
\hline (1318) & (1318) & (1316) & (1318) & (1317) & (1316) & $\begin{array}{l}1312 \\
\text { C-O stretching, Calcium } \\
\text { oxalate }\end{array}$ & (47) \\
\hline
\end{tabular}


Eur J Biol 2022; 81(1): 1-10

Kayabas and Yildirim. Biochemical and wettability analyses of Salvia adapted to gypsum soils

Table 1. Characteristic bands of ATR-FTIR spectra at Salvia absconditiflora. (continued)

\begin{tabular}{|c|c|c|c|c|c|c|c|}
\hline \multicolumn{6}{|c|}{ Salvia absconditiflora } & \multirow{2}{*}{ 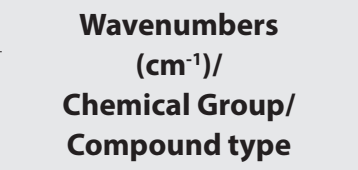 } & \multirow{2}{*}{ Ref. } \\
\hline $\operatorname{Root}\left(\mathrm{cm}^{-1}\right)$ & Stem $\left(\mathrm{cm}^{-1}\right)$ & Petiole $\left(\mathrm{cm}^{-1}\right)$ & Leaf $\left(\mathrm{cm}^{-1}\right)$ & Sepal $\left(\mathrm{cm}^{-1}\right)$ & Petal $\left(\mathrm{cm}^{-1}\right)$ & & \\
\hline$(1450,1370)$ & $(1458,1373)$ & $(1455,1374)$ & $(1457,1373)$ & $(1450,1375)$ & $(1453,1372)$ & $\begin{array}{l}\text { 1371-1450 } \\
\text { C-H deformations, } \\
\text { Phenolic (lignin) and } \\
\text { aliphatic structures }\end{array}$ & (24) \\
\hline (1429) & $(1430)$ & $(1434)$ & $(1434)$ & $(1435)$ & $(1420)$ & $\begin{array}{l}1426 \\
\text { Symmetric C-O stretch } \\
\text { from } \mathrm{COO}^{-} \text {or stretch } \\
\text { and } \mathrm{OH} \text { deformation, } \\
\text { Carboxylate/Carboxylic } \\
\text { structures (humic acids) }\end{array}$ & (49) \\
\hline$(1440-1410)$ & $(1450-1425)$ & $(1445-1425)$ & $(1470-1435)$ & (1450-1425) & $(1450-1420)$ & $\begin{array}{l}1450-1410 \\
\text { C-O stretching, Calcium } \\
\text { carbonate }\end{array}$ & $(51)$ \\
\hline (1510-1505) & $(1510-1500)$ & $(1511-1502)$ & (1510-1504) & (1511-1502) & (1512-1505) & $\begin{array}{l}1505-1515 \text { Aromatic } C= \\
\text { C stretching, } \\
\text { Lignin/Phenolic } \\
\text { backbone }\end{array}$ & (24) \\
\hline (1555) & (1550) & (1555) & (1558) & (1557) & (1558) & $\begin{array}{l}1550 \\
\mathrm{~N}-\mathrm{H} \text { in plane (amide-II), } \\
\text { Proteinaceous origin }\end{array}$ & $(50)$ \\
\hline$(1600-1650)$ & $(1630-1580)$ & $(1630-1580)$ & $(1630-1585)$ & $(1620-1590)$ & $(1640-1600)$ & $\begin{array}{l}\text { 1600-1650 (1610) } \\
\text { Aromatic C = C stretching } \\
\text { and/or asymmetric C-O } \\
\text { strech in } \mathrm{COO}^{-}, \text {Lignin } \\
\text { and other aromatics, } \\
\text { or aromatic or aliphatic } \\
\text { carboxylates }\end{array}$ & $(61)$ \\
\hline (1617) & $\left(1617 \mathrm{~cm}^{-1}\right)$ & $\left(1617 \mathrm{~cm}^{-1}\right)$ & $\left(1614 \mathrm{~cm}^{-1}\right)$ & $\left(1617 \mathrm{~cm}^{-1}\right)$ & $\left(1622 \mathrm{~cm}^{-1}\right)$ & $\begin{array}{l}1615 \\
C=O \text { streching, Calcium } \\
\text { oxalate }\end{array}$ & $(52)$ \\
\hline (1653) & (1655) & (1651) & (1655) & (1647) & (1652) & $\begin{array}{l}1653 \\
C=O \text { of amide } \mathrm{I}, \\
\text { Proteinaceous origin }\end{array}$ & (53) \\
\hline$(1707-1703)$ & $(1720-1710)$ & $(1720-1710)$ & $(1710-1700)$ & $(1710-1700)$ & (1710-1695) & $\begin{array}{l}1710-1707 \\
\mathrm{C}=\mathrm{O} \text { stretch of } \mathrm{COOH}, \\
\text { Carboxylic acids }\end{array}$ & $(61)$ \\
\hline (1735-1730) & $(1740-1720)$ & $(1740-1720)$ & $(1740-1720)$ & (1740-1718) & $(1740-1720)$ & $\begin{array}{l}1740-1720 \\
C=O \text { strech of COOR, } \\
\text { Esters }\end{array}$ & $(45)$ \\
\hline (2850) & $(2850)$ & (2850) & (2850) & (2850) & (2850) & $\begin{array}{l}2850 \\
\text { symmetric } \mathrm{CH}_{2} \text { stretching } \\
\text { Fats, waxes, lipids }\end{array}$ & $(56)$ \\
\hline (2920) & (2920) & (2920) & (2920) & (2925) & (2925) & $\begin{array}{l}2920 \\
\text { antisymmetric } \mathrm{CH}_{2} \\
\text { stretching Fats, waxes, lipids }\end{array}$ & $(57)$ \\
\hline$x$ & $x$ & $x$ & $x$ & $x$ & $x$ & $\begin{array}{l}3340 \\
\text { O-H stretching, Cellulose }\end{array}$ & $(55)$ \\
\hline$(3500-3000)$ & $(3500-3000)$ & $(3500-3000)$ & $(3500-3000)$ & $(3500-3000)$ & $(3620-3000)$ & $\begin{array}{l}\text { 3600, } 3400 \\
\text { O-H stretching, Gypsum }\end{array}$ & (54) \\
\hline
\end{tabular}


(a)

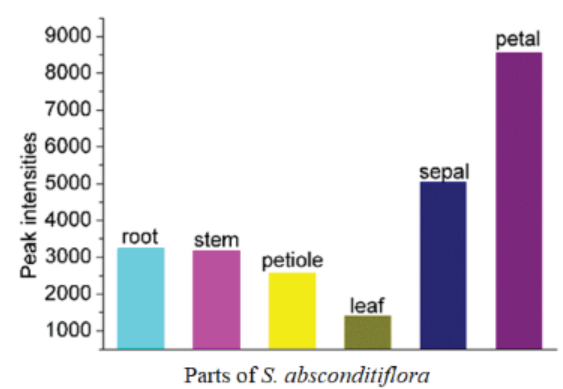

(b)

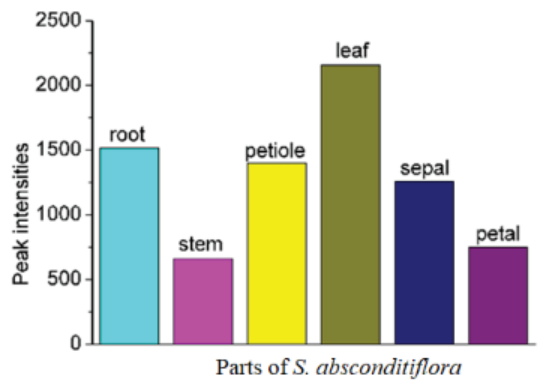

Figure 3. Peak intensities of hydroxyl (a) and aliphatic groups (b) at Salvia absconditiflora.

$\mathrm{cm}^{-1}$. It is thought that these bands overlap each other since these bands are seen distinctly and are also in the fingerprint region. $\mathrm{C}-\mathrm{O}-\mathrm{C}$ and $\mathrm{C}-\mathrm{N}$ stretch bands in lignin and amide-III structures were detected at $1280-1200 \mathrm{~cm}^{-1}$. Lignin, calcium oxalate, phenolic and aliphatic structures, carboxylate structures were referred to $\mathrm{C}-\mathrm{O}$ stretch $\left(1275-1265 \mathrm{~cm}^{-1}\right), \mathrm{C}-\mathrm{H}$ deformation (1450-1371 $\left.\mathrm{cm}^{-1}\right)$, symmetrical C-O, $\mathrm{COO}^{-}$and $\mathrm{OH}$ deformation bands (1434-1426 cm $\left.\mathrm{cm}^{-1}\right)$. C-O stretching, aromatic $\mathrm{C}=\mathrm{C}$ stretching, and $\mathrm{N}-\mathrm{H}$ bands, which belong to calcium carbonate, lignin/phenolic, and proteinaceous origin, were determined at 1450-1410, 1505-1502, and 1560-1550 cm-1 , respectively. The aromatic $\mathrm{C}=\mathrm{C}$ band containing lignin and other aromatic structures, carbonyl band originating from calcium oxalate, and protein bands known as carbonyl amides were detected at 1640-1580, 1620-1615, and 1655-1650 $\mathrm{cm}^{-1}$. The carboxylic acid carbonyl stretch band and carbonyl band of esters were also determined at 1710-1700 and 1750-1715 cm-1.

Bands of hydroxyl chemical groups originating from gypsum and cellulose were seen in plant parts from root to flower. The intensity change graph of the hydroxyl bands is shown in Figure 3a. Accordingly, the hydroxyl band intensity from root to petal was calculated as 3240, 3170, 2570, 1410, 5040, and 8560 a.u. (arbitrary units), respectively. Band intensities were determined to be different for each region. The bands belonging to symmetric and antisymmetric aliphatic carbon groups, which are considered as the main source of oils, waxes, and lipids were also observed at 2920 and $2850 \mathrm{~cm}^{-1}$ (Figure 3b). The intensity of these bands also differed according to the regions of the plant. Band intensities were measured as 1520,660, 1400, 2160, 1260, and 750 a.u. from root to petal. These results show that the band intensity changes for each part, which is valid for the hydroxyl band.

CA measurements were taken to understand the chemical composition of the leaf surfaces and their hydrophobichydrophilic interactions. The leaves were measured at regular intervals for CA measurements. The CA of the leaves divided into three regions from the petiole to the tip of the leaf was measured. According to these measurements, the CA measurements of the abaxial surface of the leaf from the petiole to the leaf tip were found to be $99.14 \pm 3.05^{\circ}, 98.42 \pm 4.41^{\circ}$ and $97.78 \pm 2.18^{\circ}$, respectively (Figure 4 ).
Three regions were selected for the adaxial surface of the leaf, and CA measurements were made for these regions. In this context, the CA measurement results were measured as $98.02 \pm 4.42^{\circ}, 95.09 \pm 4.17^{\circ}$ and $89.98 \pm 4.04^{\circ}$ in the regions determined from the petiole to the leaf tip (Figure 5). The CA measurement values on the adaxial surface differed more than the abaxial surface.

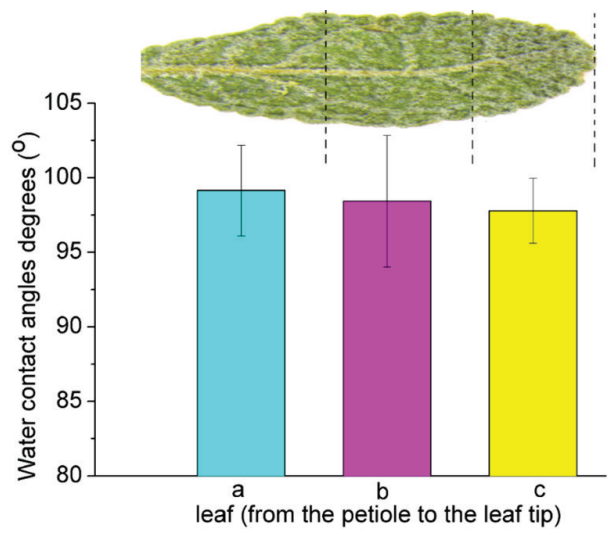

Figure 4. Contact angle measurements of the leaf abaxial surface at Salvia absconditiflora.

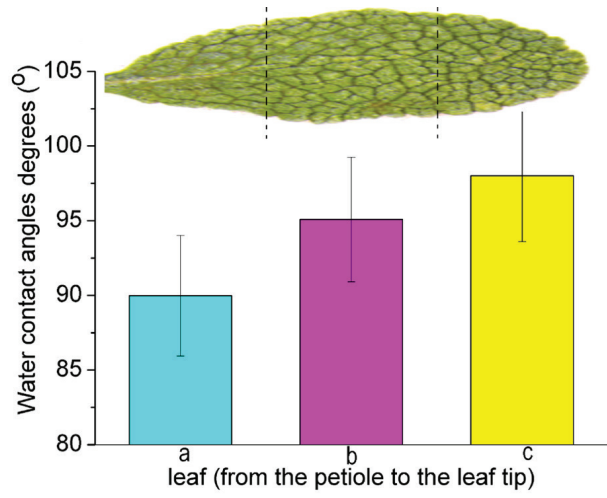

Figure 5. Contact angle measurements of the leaf adaxial surface at Salvia absconditiflora. 
Table 2. Hysteresis values.

\begin{tabular}{llll}
\hline Abaxial & & Adaxial & Hysteresis values \\
\hline Regions & Hysteresis values & Regions & 8.20 \\
\hline Leaf tip & 6.25 & Leaf tip & 1.67 \\
\hline Middle region of the leaf & 1.05 & Middle region of the leaf & 4.06 \\
\hline Petiole & 2.17 & Petiole & \\
\hline
\end{tabular}

Contact angle hysteresis $(\mathrm{CAH})$ values, a measure of surface roughness that can be determined by CA measurements, were also calculated. Leaf surfaces were considered for hysteresis values. For the $\mathrm{CAH}$ of the abaxial and adaxial surfaces, the differences between the values of the advancing and receding CAs taken from three different regions of each surface were taken. The $\mathrm{CAH}$ values of the adaxial and abaxial surfaces of the leaf were different (Table 2).

This study aims to investigate the chemical profile and wettability of S. absconditiflora. In this context, a series of results based on ATR-FTIR spectroscopy and CA measurements were obtained. With the help of ATR-FTIR, the chemical profile of the S. absconditiflora was obtained and the types of possible chemical structures in this plant were determined. In particular, the ATR-FTIR spectra taken from the root, stem, petiole, leaf, sepal, and petal of the S. absconditiflora were compared, and which chemical components were more abundant was determined by the change of band intensities.

In the ATR-FTIR spectra from the plant parts of S. absconditiflora, the bands were similar, but there were variations in the intensities and wavenumbers of some bands. The values of the shifts in the bands are given in Table 1. It is thought that the shifts in the number of waves seen in the bands detected in the ATR-FTIR spectra do not change much chemically, but the change in band values may be because of the extreme habitat in which this plant species lives.

The changes in band intensities show that $S$. absconditiflora contains different amounts of chemicals in each plant part. The intensities of the bands belonging to the hydroxyl and aliphatic groups, in which the band area can be easily detected, were compared among the spectra. It was calculated that the hydroxyl band had different areas ranging from the root to the petal. This proves that the amount of gypsum or cellulose in the plant varies according to the plant parts (Table 1, Figure 3a). Band intensities for the relative amounts of oils, lipids and waxes compounds were calculated from the ATR-FTIR spectra. It was determined that the band intensities changed according to the chemical amounts in each plant part (Table 1, Figure 3b).

As a result of the CA measurements taken from different parts of the S. absconditiflora leaf, it was observed that there were more changes, especially on the adaxial surface compared to the abaxial surface. The difference between the CAs changed more from region to region on the adaxial surface. The CA on the abaxial surface showed a change of about $10^{\circ}$ from petiole to leaf tip. Contrary to this situation, on the abaxial surface, a $2^{\circ}$ change was observed in the CAs. It can be said that the stability of the CA in the abaxial part of the leaf is due to less contact with environmental conditions than the adaxial surface. The source of the changes in the CA on the adaxial surface may be because the sun's rays do not touch the leaf surface at the same angle. It is thought that the sun's rays remove the water on the leaf, making it more hydrophobic than the abaxial surface.

When the hydrophobicity of the $S$. absconditiflora leaf is examined in detail, CAs on the adaxial surface of the leaf is average $\sim 94^{\circ}$, while it is average $\sim 98^{\circ}$ on the abaxial surface (Adaxial ${ }_{C A}<$ Abaxial $_{C A}$ ). It can be said that the adaxial and abaxial surfaces of the S. absconditiflora leaf are hydrophobic according to the results of the CAs (Adaxial hidrofobicity $<$ Abaxial $_{\text {hidrofobicity). }}$ ). However, while the CA was higher on the adaxial surface of the leaf, the hysterization of the abaxial surface of the leaf was higher (Adaxial hysterise Abaxial $_{\text {hysterise }}$ ). The hysterization of the adaxial surface of the leaf averages $\sim 4.6^{\circ}$, while the abaxial surface averages $\sim 3.2^{\circ}$.

\section{DISCUSSION}

The chemical groups and band intensities of the root, stem, leaf, petiole, sepal, and petal of S. absconditiflora were measured by using ATR-FTIR. In the literature, bands have been reported for calcium, sulphate, silicate, phosphate, polysaccharide, lipid, aromatic compounds, phenolic compounds, and protein-based structures in the ATR-FTIR spectra taken especially for gypsum plants $(24,37-53)$. Band intensities varied between plant parts from root to flower. Palacio et al. reported that band densities of wide and narrow gypsum plants varied between ecological plant groups (24). In this study, it was understood that the band types did not change much in the ATR-FTIR spectra taken for the vegetative and generative plant parts of the S. absconditiflora, but the band intensities differed. In this case, where the hydroxyl band of gypsum $(54,55)$, whose intensity can be measured, differs for each plant parts, it was shown that the amount of gypsum varied in the root, stem, leaf, petiole, and flower. Likewise, the observation of differences in the band intensities of symmetric and asymmetrical aliphatic carbons, which are the basis of oils, waxes, and lipids, showed that the plant parts have different chemical contents $(56,57)$. In general, the presence of each specific band was detected in the ATR-FTIR spectra taken, 
but it was understood that the same trend was observed for all plant parts where the band intensities were different.

Since gypsum plants grow in gypsum soils, they have the potential to be an accumulator of calcium and sulfur (58). Ozdemir et al. reported the presence of the calcium mineral in Gypsophila taxa and that it can be used as an accumulator (59). The presence of chemical bands in calcium carbonate and calcium oxalate compounds, which are thought to be calcium sources for each plant part in the ATR-FTIR spectra, indicates that S. absconditiflora may be an accumulator in terms of calcium content. Another mineral frequently seen in gypsum plants is sulfur and it has been reported that it can act as an accumulator (58). Sulfur-derived bands, especially in the structure of sulphates, were detected in each of the plant parts and it was understood from the band intensities that this plant species is rich in terms of the sulfur mineral. In addition to these two minerals, the presence of organic compounds (aromatic, phenolic, etc.) and proteinbased structures revealed that the plant species is also rich in organic compounds (24). The high intensities of the hydroxyl bands originating from gypsum indicate that the water content and gypsum content of S. absconditiflora are high. In terms of adaptation to harsh conditions, the presence of important minerals in S. absconditiflora, as well as the presence of organic compounds, will help in the process of understanding adaptation.

Wang et al. observed that the CAs and hysterization of the adaxial and abaxial surfaces on the lotus leaf were also different and mentioned two types of surface descriptions of plants with hydrophobic properties and stated that leaves such as lotus exhibited a typical feature in investigating the hydrophobicity of various plant leaves (32). The hydrophobicity and hysterization of the S. absconditiflora leaf support the results in the lotus leaf. Legrand et al. also recorded the hydrophobicity and hysteresis of three natural leaves, describing their wetting behavior, and modeled the relationship between surface roughness, wettability, and leaf behavior (34). Hysteresis values also help to prove the existence of inorganic compounds in the plant. Katata and Held tested the presence of inorganic compounds in a spruce forest with the hysteresis effect (60). The structure of superhydrophobic surfaces such as lotus leaves and rose petals is due to the fine architectural features created by nature, and the superhydrophobic behavior of these organic surfaces in fields such as chemistry has also inspired the creation of surfaces with synthetic molecules (62). This study, inspired by the lotus effect of the S. absconditiflora plant, which has a surface feature like a lotus leaf, can contribute to the formation of synthetic surfaces in other fields of science. As well as contributing to the formation of synthetic molecules, knowing the morphology and wettability of the leaf also guides the retention of pesticides used in sustainable agriculture on the leaf (63). Similar studies are also important in agriculture as well as plant ecology.

\section{CONCLUSION}

In summary, in the first step of this study, the chemical profile of the root, stem, petiole, leaf, sepal, and petal of
S. absconditiflora was extracted using the ATR-FTIR technique. Using this technique, possible compounds that might be found in the structure of the plant were determined. Due to the different band intensities of each plant part in terms of compound content, it was understood that the compound amounts of each structure was different from region to region. In the second stage, detailed wettability, and hysteresis results of the abaxial and adaxial surfaces of the leaves were evaluated. The leaves were divided into three different regions on the petiole up to the tip, and CA measurements were made for both sides (adaxial and abaxial). It was determined that the adaxial surface was more hydrophobic than the abaxial surface, and the CAs were less stable. It was discussed that this situation will play a key role in understanding the adaptation of the S. absconditiflora plant to extreme conditions. At the same time, by calculating the hysteresis results of the surfaces, it was announced that this plant species has similar characteristics as the lotus plant. As a result, detailed wettability, and hysteresis profiles of both chemical and leaves of the S. absconditiflora plant were created for the first time in the literature. With this study, important clues about the adaptation of plants to harsh conditions were obtained. Thus, this study paves the way for many future studies to determine what kinds of chemical structures and wettability parameters are required to prevent the future extinction of plant species that cannot keep up with extinction or difficult conditions in the world.

Acknowledgements: The authors would like to thank the Gazi University Academic Writing and Research Center for their help and valuable support in the proofreading of this study.

Informed Consent: Written consent was obtained from the participants.

Peer Review: Externally peer-reviewed.

Author Contributions: Conception/Design of Study- A.K., E.Y.; Data Acquisition- A.K., E.Y.; Data Analysis/Interpretation- A.K., E.Y.; Drafting Manuscript- A.K., E.Y.; Critical Revision of Manuscript- A.K., E.Y.; Final Approval and Accountability- A.K., E.Y.

Conflict of Interest: Authors declared no conflict of interest.

Financial Disclosure: Authors declared no financial support.

\section{REFERENCES}

1. Firat M. Stachys semsurensis (Lamiaceae), a new species from Adıyaman province (Turkey) belonging to section. Infrarosularis. Phytotaxa 2021; 511: 275-82.

2. Hedge IC. Lamiaceae of south-west Asia: diversity, distribution and endemism. Proc Royal Soc B 1986; 89: 23-5.

3. Yaris E, Adsız LB, Yener I, Tuncay E, Yilmaz MA, et al. Isolation of secondary metabolites of two endemic species: Salvia rosifolia Sm. and Salvia cerino-pruinosa Rech. f. var. elazigensis (Lamiaceae). J Food Meas 2021; 1-10.

4. Baytop T. Therapy with medicinal plants in Turkey. Istanbul: Nobel Medical Press; 1999. 
5. Singh B, Singh B, Kishor A, Singh S, Bhat MN, et al. Exploring plantbased ethnomedicine and quantitative ethnopharmacology: Medicinal plants utilized by the population of Jasrota Hill in Western Himalaya. Sustainability 2020; $12: 7526$.

6. Tundis R, Leporini M, Bonesi M, Rovito S, Passalacqua NG. Salvia officinalis L. from Italy: A comparative chemical and biological study of its essential oil in the mediterranean context. Molecules 2020; 25: 5826.

7. Hedge IC. Salvia L. Davis PH, editor. Flora of Turkey and the East Aegean Islands. Edinburgh: Edinburgh University Press; 1982. p. 400-61.

8. Davis PH, Mill RR, Tan K. Flora of Turkey and the East Aegean Islands (Vol X). Edinburgh: Edinburgh University Press; 1988.

9. Vural M, Adıgüzel N. A new species from Central Anatolia: Salvia aytacii M. Vural \& N. Adıgüzel (Labiatae). Turk J Bot 1996; 20: 53134.

10. Celep F, Raders E, Drew B. Two new hybrid species of Salvia (S. $\times$ karamanensis and S.Xdoganii) from Turkey: Evidence from molecular and morphological studies. Turk J Bot 2020; 44: 647-60.

11. Akkol EK, Göger F, Koşar M, Başer KHC. Phenolic composition and biological activities of Salvia halophila and Salvia virgata from Turkey. Food Chem 2008; 108: 942-49.

12. Sindhuja R, Rajendran A, Jayanthi P. Herbaceous life forms of Maruthamalai Hills, Southern Western Ghats, India. Int J Med Aromat Plants 2012; 2: 625-31.

13. Ozbey BG, Ozdeniz E, Bolukbaşi A, Oktem M, Keleş Y, et al. The role of free proline and soluble carbonhydrates in serpentine stress on some serpetinophyte and serpentinovag plants. Acta Biologica Turcica 2017; 30: 146-51.

14. Soriano P, Moruno F, Boscaiu M, Vicente O, Hurtado A, et al. Is salinity the main ecologic factor that shapes the distribution of two endemic Mediterranean plant species of the genus Gypsophila? Plant Soil 2014; 384: 363-79.

15. Westworth S, Ashwath N, Cozzolino D. Application of FTIR-ATR spectroscopy to detect salinity response in Beauty Leaf Tree (Calophyllum inophyllum L). Energy Procedia 2019; 160: 761-68.

16. Acosta-Motos JR, Ortuño MF, Bernal-Vicente A, Diaz-Vivancos $P$, Sanchez-Blanco MJ, et al. Plant responses to salt stress: Adaptive mechanisms. Agronomy 2017; 7: 18.

17. Barer R, Cole ARH, Thompson HW. Infra-red spectroscopy with the reflecting microscope in physics, chemistry and biology. Nature 1949;163:198-201.

18. Legner N, Meinen C, Rauber R. Root differentiation of agricultural plant cultivars and proveniences using FTIR spectroscopy. Front Plant Sci 2018; 9: 748.

19. Götz A, Nikzad-Langerodi R, Staedler Y, Bellaire A, Saukel J. Apparent penetration depth in attenuated total reflection Fourier-transform infrared (ATR-FTIR) spectroscopy of Allium cepa L. epidermis and cuticle. Spectrochim Acta A Mol Biomol Spectrosc 2020;224:117460.

20. Kazarian SG, Chan KLA. Applications of ATR-FTIR spectroscopic imaging to biomedical samples. Biochim Biophys Acta Biomembr 2006;1758:858-67.

21. Ferreira IC, Aguiar EM, Silva AT, Santos LL, Cardoso-Sousa L, et al. Attenuated Total Reflection-Fourier Transform Infrared (ATR-FTIR) spectroscopy analysis of saliva for breast cancer diagnosis. J Oncol 2020; 4343590.

22. Ivanova DG, Singh BR. Nondestructive FTIR monitoring of leaf senescence and elicitin-induced changes in plant leaves. Biopolymers: Original Research on Biomolecules 2003; 72: 79-85.

23. Wahab MA, Boubakri $H$, Jellali $S$, Jedidi N. Characterization of ammonium retention processes onto Cactus leaves fibers using FTIR, EDX and SEM analysis. J Hazard Mater 2012; 241: 101-9.
24. Palacio S, Aitkenhead M, Escudero A, Montserrat-Martí G, Maestro $M$ et al. Gypsophile chemistry unveiled: Fourier transform infrared (FTIR) spectroscopy provides new insight into plant adaptations to gypsum soils. PLoS One 2014; 9: e107285.

25. Woutersen A, Jardine PE, Bogotá-Angel RG, Zhang HX, Silvestro D, et al. A novel approach to study the morphology and chemistry of pollen in a phylogenetic context, applied to the halophytic taxon Nitraria L. (Nitrariaceae). PeerJ 2018; 6: e5055.

26. Debnath M, Ashwath N, Hill CB, Callahan DL, Dias DA, et al. (2018). Comparative metabolic and ionomic profiling of two cultivars of Stevia rebaudiana Bert. (Bertoni) grown under salinity stress. Plant Physiol Biochem 2018; 129: 56-70.

27. Aswathappa N, Munns R, Bachelard EP, Tonnet ML. lon concentrations in the xylem sap of two Casuarina species differing in salt tolerance. Proceedings of the 7th International Workshop on Plant Membrane Transport (Membrane Transport in Plants and Fungi). Sydney: University of Sydney Publication; 1986. p. 486-489.

28. Huhtamäki T, Tian X., Korhonen JT, Ras RH. Surface-wetting characterization using contact-angle measurements. Nat Protoc 2018; 13: 1521-38.

29. Yokoyama G, Yasutake D, Tanizaki T, Kitano M. Leaf wetting mitigates midday depression of photosynthesis in tomato plants. Photosynthetica 2019; 57: 740-7.

30. Yokoyama G, Yasutake D, Minami K, Kimura K, Marui A, et al. Evaluation of the physiological significance of leaf wetting by dew as a supplemental water resource in semi-arid crop production. Agric Water Manag 2021;255:106964.

31. Roy T, Sabharwal TP, Kumar M, Ranjan P, Balasubramaniam R. Mathematical modelling of superhydrophobic surfaces for determining the correlation between water contact angle and geometrical parameters. Precis Eng 2020; 61: 55-64.

32. Wang J, Chen H, Sui T, Li A, Chen D. Investigation on hydrophobicity of lotus leaf: Experiment and theory. Plant Sci 2009;176:687-95.

33. Neinhuis C, Barthlott W. Characterization and distribution of water-repellent, self-cleaning plant surfaces. Ann Bot 997; 79: 667-77.

34. Legrand Q, Benayoun S, Valette S. Biomimetic approach for the elaboration of highly hydrophobic surfaces: Study of the links between morphology and wettability. Biomimetics 2021; 6: 38.

35. Davis PH, Mill RR, Tan K. Flora of Turkey and the East Aegean Islands (Vol XII). Edinburgh: Edinburgh University Press; 1982.

36. Ozcan AU, Aytaş I. Temporal landscape change in biodiversity hotspot and geological heritage karst landscapes: Çankırı gypsum hills case. Yuzuncu Yil Univ J Agric Sci 2019; 29: 618-27.

37. Boke $\mathrm{H}$, Akkurt $\mathrm{S}$, Ozdemir S, Goktürk EH, Saltik ENC. Quantification of $\mathrm{CaCO}_{3}-\mathrm{CaSO}_{3} \cdot 0.5 \mathrm{H}_{2} \mathrm{O}-\mathrm{CaSO}_{4} \cdot 2 \mathrm{H}_{2} \mathrm{O}$ mixtures by FTIR analysis and its ANN model. Mater Lett 2004; 58: 723-6.

38. Shillito LM, Almond MJ, Nicholson J, Pantos M, Matthews W. Rapid characterisation of archaeological midden components using FTIR spectroscopy, SEM-EDX and micro-XRD. Spectrochim Acta A Mol Biomol Spectrosc 2009; 73: 133-9.

39. Ennaciri Y, Bettach M, Cherrat A, Zegzouti A. Conversion of phosphogypsum to sodium sulfate and calcium carbonate in aqueous solution. J Mater Environ Sci 2016; 7: 1925-33.

40. Zaccheo P, Cabassi G, Ricca G, Crippa L. Decomposition of organic residues in soil: Experimental technique and spectroscopic approach. Org Geochem 2002; 33: 327-45.

41. Liu D, Tian H, Jia X, Zhang L. Effects of calcium carbonate polymorph on the structure and properties of soy protein-based nanocomposites. Macromol Biosci 2008; 8: 401-9.

42. Ma F, Huang AM, Zhang SF, Zhou Q, Zhang QH. Identification of three Diospysros species using FT-IR and 2DCOS-IR. J Mol Struct 2020; 1220: 128709. 
43. Ferreira ML, Gerbino E, Cavallero GJ, Casabuono AC, Couto AS, et al. Infrared spectroscopy with multivariate analysis to interrogate the interaction of whole cells and secreted soluble exopolimeric substances of Pseudomonas veronii $2 \mathrm{E}$ with Cd (II), Cu (II) and Zn (II). Spectrochim Acta A Mol Biomol Spectrosc 2020; 228: 117820.

44. Jastrzębski W, Sitarz M, Rokita M, Bułat K. Infrared spectroscopy of different phosphates structures. Spectrochim Acta A Mol Biomol Spectrosc 2011; 79: 722-27.

45. Smidt E, Meissl K. The applicability of fourier transform infrared (FT-IR) spectroscopy in waste management. Waste Manage 2007; 27: 268-76.

46. Li C, Du C, Ma F, Zhou J. Diagnosis of nitrogen status in Chinese cabbage (Brassica rapa chinensis) using the ratio of amide II to amide I in leaves based on mid-infrared photoacoustic spectroscopy. J Plant Nutr Soil Sci 2015; 178: 888-95.

47. Frost RL, Yang J, Ding Z. Raman and FTIR spectroscopy of natural oxalates: Implications for the evidence of life on Mars. Chin Sci Bull 2003; 48: 1844-52.

48. Sun XF, Jing Z, Fowler P, Wu Y, Rajaratnam M. Structural characterization and isolation of lignin and hemicelluloses from barley straw. Ind Crops Prod 2011; 33(3): 588-98.

49. Parvan L, Dumitru M, Sîrbu C, Cioroianu T. Fertilizer with humic substances. Rom Agric Res 2013; 30: 205-12.

50. Centeno SA, Guzman MI, Yamazakikleps A, Védova COD. Characterization by FTIR of the effect of lead white on some properties of proteinaceous binding media. J Am Inst Conserv 2004; 43: 139-50.

51. Jamarun N, Yuwan S, Juita R, Rahayuningsih J. Synthesis and characterization carbonate apatite from bukit tui limestone padang Indonesia. J Appl Chem 2015; 4: 542-9.

52. Valarmathi D, Abraham L, Gunasekaran S. Growth of calcium oxalate monohydrate crystal by gel method and its spectroscopic analysis. Indian J Pure Appl Phys 2010; 48: 36-8.
53. De Campos Vidal B, Mello MLS. Collagen type I amide I band infrared spectroscopy. Micron 2011; 42: 283-89.

54. Mandal PK, Mandal TK. Anion water in gypsum $\left(\mathrm{CaSO}_{4} \cdot 2 \mathrm{H}_{2} \mathrm{O}\right)$ and hemihydrate $\left(\mathrm{CaSO}_{4} \cdot 1 / 2 \mathrm{H}_{2} \mathrm{O}\right)$. Cem Concr Res 2002; 32: 313-16.

55. Terpáková E, Kidalová L, Eštoková A, Čigášová J, Števulová N. Chemical modification of hemp shives and their characterization. Procedia Eng 2008; 42: 931-41.

56. Xin X, Si W, Yao Z, Feng R, Du B, et al. Adsorption of benzoic acid from aqueous solution by three kinds of modified bentonites. $J$ Colloid Interface Sci 2011; 359: 499-504.

57. Johnston A, Rogers K. A study of the intermolecular interactions of lipid components from analogue fingerprint residues. Sci Justice 2018; 58: 121-7.

58. Bolukbasi A, Kurt L, Palacio S. Unravelling the mechanisms for plant survival on gypsum soils: an analysis of the chemical composition of gypsum plants from Turkey. Plant Biol 2016; 18(2): 271-9.

59. Ozdemir C, Ozkan M, Kandemir A. The morphological and anatomical properties of Gypsophila lepidioides Boiss (Caryophyllaceae) endemic to Turkey. Int Res J Plant Sci 2010; 1: 69-74.

60. Katata G, Held A. Combined measurements of microscopic leaf wetness and dry-deposited inorganic compounds in a spruce forest. Atmos Pollut Res 2021; 12: 217-24.

61. Utami SNH, Suswati D. Chemical and spectroscopy of peat from West and Central Kalimantan, Indonesia in relation to peat properties. Int J Environ Agric Res 2016; 2: 45-52.

62. Mukhopadhyay RD, Vedhanarayanan B, Ajayaghosh A. Creation of "Rose Petal" and "Lotus Leaf" effects on alumina by surface functionalization and metal-ion coordination. Angew Chem 2017; 129(50): 16234-8.

63. Wei J, Tang Y, Wang M, Hua G, Zhang Y, Peng R. Wettability on plant leaf surfaces and its effect on pesticide efficiency. Int J Precis Agric Aviat 2020; 3(1): 30-7. 